\title{
A bronze earring in the Tropenmuseum Amsterdam
}

One of the major contributions of Pauline Lunsingh Scheurleer to the study of ancient Indonesian art concerns her study of bronze statuettes and ritual objects, which she presented in the exhibition 'Divine Bronze', held in Amsterdam in 1988, and in the accompanying catalogue of the same title. ${ }^{1}$ When Pauline asked me to assist her in that project, I had just graduated and was still working on my PhD thesis. The extent of my assistance was therefore limited. Rather, for me, it was a great opportunity to learn immensely from Pauline's object-based approach and years of experience in seeing and handling the objects themselves. Because our cooperation as colleagues began with the subject of bronzes, it seems fitting to discuss here, on the occasion of her $65^{\text {th }}$ birthday a bronze object, one which Pauline herself suggested that I should write about, and one which, as of old, we recently went to look at together.

\section{Description}

The object is a bronze earring kept in the Tropenmuseum in Amsterdam (figs. 1 and 2). It was collected by A.W. Gall, who lived in Surabaya in the 1930s. At the instigation of W.F. Stutterheim, a well-known archaeologist at the time and head of the Archaeological Service in the Netherlands Indies, he explored Mount Penanggungan, to the south of Surabaya, in 1935 in search of ancient monuments. After his exploration W.F. Stutterheim joined him to visit the monuments and to describe them. ${ }^{2}$ In July 1936 the Archaeological Service of the Dutch East Indies began to excavate, measure, and restore these monuments as far as possible. ${ }^{3} \mathrm{Mr}$. Gall died in 1944 in a Japanese camp in the Dutch East Indies. ${ }^{4}$ He had a large collection (more than 300 pieces) of ancient Javanese objects, mainly bronzes and gold objects, some of them beautiful pieces. ${ }^{5}$ His widow, Mrs. Gall-Hessels - Mrs Meijer-Hessels after she remarried - gave this collection on loan to the University of Amsterdam in 1947. In 1960 the University of Amsterdam in its turn gave it on loan to the Tropenmuseum. In 1992 this loan was turned into a donation. The earring is $3.7 \mathrm{~cm}$. in height and $3.5 \mathrm{~cm}$. in width and it weighs circa 150 grams. ${ }^{6}$ It consists of a spiral-shaped bar, both ends of which are in the form of a kinnari, a mythical female being with a human face and breasts and a bird's body, tail, wings and feet. It is thought to originate from Java and to date to the Central Javanese period ( $8^{\text {th }}$ to early $10^{\text {th }}$ century). It is an interesting object for several reasons: firstly not many bronze earrings are known to have survived from the ancient Javanese period; secondly there is only one earring; thirdly the spiral shape is not a common form for ancient Javanese earrings; and fourthly the occurrence of kinnaris on an earring is unique. Let me discuss each of these characteristics. 

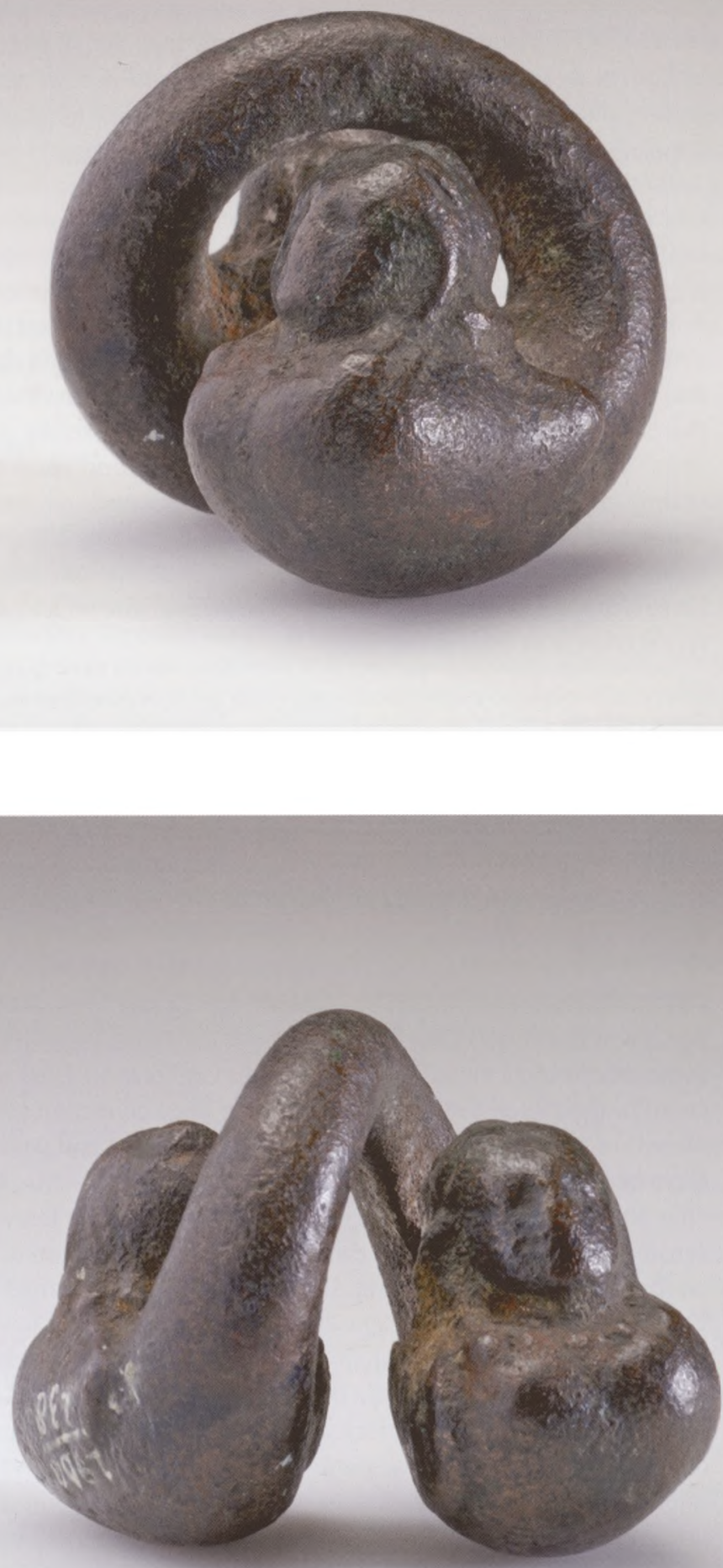

Downloaded from Brill.come4/26/2023 11:45:12AM via free access 
Figure 1

Earring, bronze,

$3.7 \times 3.5 \mathrm{~cm}$., side view, Tropenmuseum Amsterdam 2960-238. Photo Tropenmuseum

Figure 2

Earring, bronze, front view, Tropenmuseum Amsterdam 2960-238. Photo Tropenmuseum
Most earrings from the Central Javanese period that have been published are gold earrings, not bronze ones. Bronze is less expensive and less prestigious than gold. One would therefore suppose that the earring belonged to a commoner, or at least someone who did not belong to the elite. This raises the question of why so few bronze earrings have been found. In present-day Java even commoners buy gold jewellery as soon as they can afford it. Was this also the case in ancient Java? If commoners did wear bronze earrings, one would expect such earrings to have been found in greater numbers than gold earrings. Were they not published because of their plain forms? Or were they melted down more commonly than the gold examples? Were bronze earrings such as this nicely decorated one used on specific occasions only? Or did this piece come from the periphery of the Central Javanese kingdom, where gold was not easily available? Unfortunately, we will probably never know. One consequence of the use of bronze is that this earring is much heavier than most ancient Javanese ear ornaments. As mentioned above, it weighs circa 150 grams, while most ancient Javanese gold ear ornaments do not weigh more than 10 grams. $^{7}$

\section{A single earring}

As mentioned above, this earring has survived as a single earring. There is no second one to form a pair to be worn in each ear. Two explanations can be given: either the other earring got separated from this one and was melted down, got lost, or has survived in an unknown collection; or there never was another earring to match this one, and it was worn in one ear only. In some Indonesian cultures earrings were traditionally worn only in one ear. For instance, in Nias men wore ear ornaments in the right ear, while women wore them in both ears, ${ }^{8}$ and in Sumba ear ornaments (mamuli) are apparently sometimes worn by girl dancers ${ }^{9}$ and by men ${ }^{10}$ in one earlobe. Another possibility is that this earring was worn with an earring of another shape. In the narrative reliefs depicting the Ramayana story at the Loro Jonggrang temple complex in Prambanan (Central Java, $9^{\text {th }}$ century) one often finds men and women depicted with two earrings of different shapes. ${ }^{11}$

\section{A spiral shape}

The earring does not have an opening to fit it to the ear. The spiral shape makes one wonder how this bronze earring was worn. Such a spiral shape is not found in the gold ear ornaments from ancient Java that have so far been published. Gold ear ornaments are most commonly S- or U-shaped ear pendants, variously shaped ear clips, large round ear studs, or circular earrings. ${ }^{12}$ Some of the gold earrings that John Miksic attributes to what he terms 'protoclassic period' (AD 200-700) bear a resemblance to the bronze earring discussed here, because of their twisted, spiral-like forms. ${ }^{13}$ The particular spiral form of the bronze earring seems, however, to link up best with similarly shaped earrings known from Kalimantan and Sarawak. ${ }^{14}$ These are made of brass, hornbill beak or deer antler. Instead of kinnaris these examples show the head of a mythical open-mouthed half-dragon called aso at the two ends of the spiral-shaped bar. ${ }^{15}$ They are worn in elongated earlobes with holes big enough for the earrings to be fitted in and to 3311 ing:12AM 


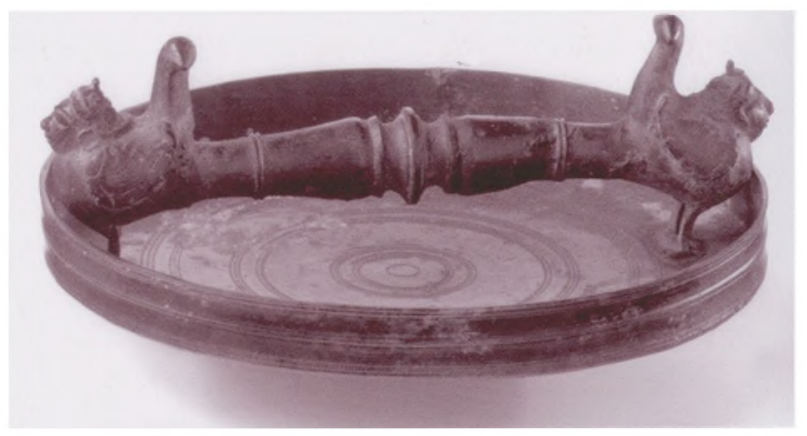

Figure 3 (left)

Mirror, bronze, private collection Amsterdam.

Photo Documentation

Centre for Ancient

Indonesian Art Amster-

dam

Figure 4

Lamp, bronze, Tropenmuseum Amsterdam, inv.no. 1770-65. Photo Tropenmuseum

\section{Kinnaris}

from the long earlobes. ${ }^{16}$ This must also have been the way the bronze earring with kinnaris was attached to the ear.

This bronze earring is unique because the two ends of its spiral-shaped bar are in the form of kinnaris, female beings with a human face and women's breasts, and a bird's body with wings and feet. The bird's tail merges with the spiral-shaped bar which connects the two kinnaris. I do not know of any other ancient Javanese earring with this motif. Kinnaris and kinnaras, their male companions, are, however, found on a variety of objects in Central Javanese art. Occasionally the motif appears on other bronze objects, for instance the unique mirror in figure 3 , which has two kinnaras on the ends of the handle at the rear side of the mirror. ${ }^{17}$ More common are bronze oil lamps in the shape of kinnaris. The example presented here was, like the bronze earring, collected by A.W. Gall (fig. 4). Kinnaras and kinnaris abound on Central Javanese temples: they can be found in narrative reliefs (fig. 5), or in a variety of auspicious ornaments (fig. 6).

Borobudur contains depictions of kinnaras and kinnaris in quite a number of locations: in the narrative reliefs on the hidden base, the first balustrade, and the first, second, and third main walls; and as an ornament at the top of the archways to the second and the fourth gallery and in the foliate spiral ornament that divides the narrative panels of the fourth main wall. We find two types of kinnaras: one type that stands upright and has a human body down to the waist and arms (cf. fig. 5) and another type that sits as a bird and does not have a human body, except for breasts on the female figures. In the narrative reliefs of the hidden base they occur in pairs, usually a male and a female, on either side of a heavenly wishing tree (kalpataru). ${ }^{18}$ The motif of a wishing tree with a kinnara and kinnari refers in these reliefs to the heaven that awaits those who perform good deeds. If the kinnaras and kinnaris have $12 \mathrm{AM}$ 

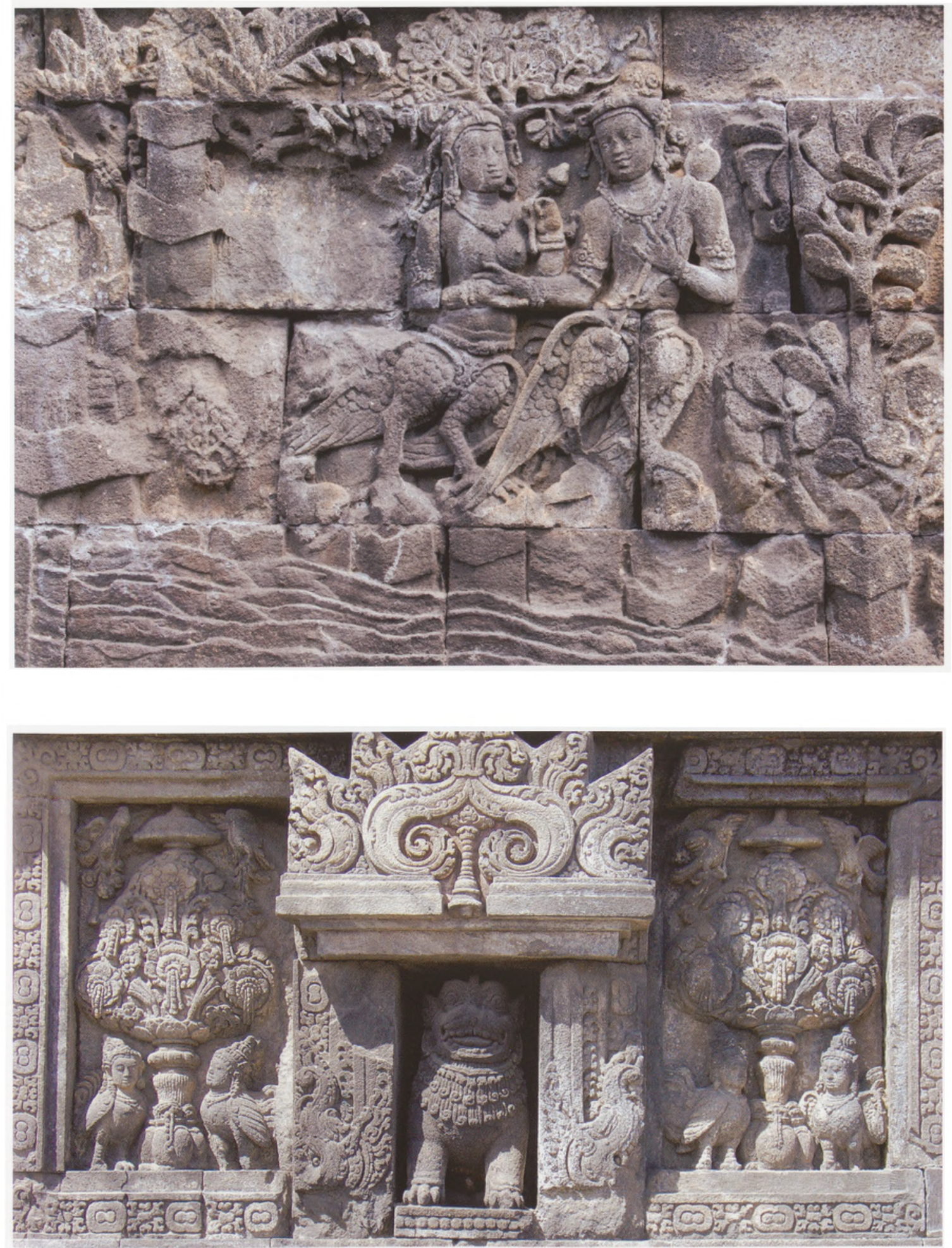

Figure 5 (above)

Narrative relief (I b 89),

Borobudur. Photo

Marijke Klokke
Figure 6

Ornamental panel,

Brahma temple, Loro

Jonggrang. Photo

Marijke Klokke
Downloaded from Brill.com $\odot 4 / 26 / 2023$ 11:45:12AM 
arms they hold musical instruments in their hands (as in figure 5). The first balustrade shows in separate panels the same ornament of a wishing tree with a kinnara and kinnari. ${ }^{19}$ The first main wall presents these heavenly beings in other contexts. In the lower series we find a relief that shows a person holding a tray with two small objects in the form of kinnaras (of the type without arms). ${ }^{20}$ There is also a seated man who is holding a similarly shaped object and painting it. Yet another person is offering such a miniature kinnara, probably made of clay or wood, to a king who is sitting on a throne with his wife, while a child, probably their child, stands behind them. ${ }^{21}$ Are these toys, as Bernet Kempers suggests, or gifts to mark a rite de passage, such as a birth or a marriage, as such gifts are, according to Bernet Kempers, still made in India for such occasions? ${ }^{22}$ Also, in this lower series on the main wall we find the moving story of the love of a male and female couple of kinnaras, who wept for 700 years because they had been separated for one night (fig. 5). ${ }^{23}$ In the narrative reliefs of the second and third main wall of Borobudur we can observe kinnaras and kinnaris sitting on clouds, flying in the air or perching on trees, thus suggesting a heavenly sphere. ${ }^{24}$ As an ornament, kinnaras abound on Central Javanese temples: as an ornament in its own right, for instance over the entrances of the large secondary shrines of the Sewu complex, Banyunibo, the main temple of Ijo, and the twin temples of Plaosan Lor, over niches at temple II of Ngawen, to the sides of the windows of Sari, and on the staircase of Badut in East Java, or as part of another ornament, for instance the kalpataru ornament as on Mendut, Pawon, Loro Jonggrang (fig. 6), and the staircase of Sojiwan, the spiral ornament as on Pringapus, or the garland ornament as on Badut, Gunung Wukir, and Loro Jonggrang. Whereas two types were known during the early Central Javanese period (circa $8^{\text {th }}$ century), one with arms (fig. 5) and one more bird-like; the latter type is the only one that survived during the later Central Javanese period (circa $9^{\text {th }}$ century). Still later, in the East Javanese period, this also disappeared and kinnaras and their female companions were no longer depicted in Java.

\section{Conclusion}

The earring is interesting because it combines a pre-classic spiral form with the classic Central Javanese motif of a kinnari. Its shape bears a likeness in particular to spiral-shaped earrings from Kalimantan with the aso motif. The bronze earring belongs to the Central Javanese period ( $8^{\text {th }}$ to early $10^{\text {th }}$ century), because the occurrence of the kinnara motif is limited to that period. It is not possible to be more precise. Since the kinnaris on this earring do not have arms they could belong either to the early Central Javanese period (circa $8^{\text {th }}$ century) or to the later Central Javanese period (circa $9^{\text {th }}$ century). It is still a riddle who wore this earring and to what social class he or she belonged. Kinnaris, such as the ones that decorate this earring, are associated with heaven and true love. On this earring we do not, however, find a male and female couple. Apparently these two kinnaris have not found their true love yet. Could this earring have been the earring of a young female who was of an age to be married off? A symbol referring to heaven and true love would be promising in such a context. In general, the motif of a kinnari is an auspicious and promising symbol, and as such also appropriate in the context of this felicitative volume. 
Budaya Indonesia; kunst en cultuur in Indonesië / arts and crafts in Indonesia (cat. Tropenmuseum), Amsterdam, 1987.

E.B. Cowell (ed.), The Jataka or stories of the Buddha's former births, London, 1973.

N.J. Krom and T. van Erp, Beschrijving van Barabudur (Archaeologisch Onderzoek in Nederlandsch-Indië 3), The Hague, 1920-1931.

P. Lunsingh Scheurleer and Marijke J. Klokke, Divine bronze: ancient Indonesian bronzes from $A D 600$ to 1600; catalogue of the exhibition organised in collaboration with the Society of Friends of Asiatic Art held in the Department of Asiatic Art, Rijksmuseum, Amsterdam, April 30-July 31, 1988. Leiden, 1988 (Lunsingh Scheurleer en Klokke 1988a).

P. Lunsingh Scheurleer and Marijke J. Klokke, Ancient Indonesian bronzes; a catalogue of the exhibition in the Rijksmuseum Amsterdam with a general introduction, Leiden etc., 1988 (Lunsingh Scheurleer en Klokke 1988b).

J.N. Miksic, Small finds; ancient Javanese gold (cat. Southeast Asian Gallery, National Museum), Singapore, 1988.

J.N. Miksic, Old Javanese gold, Singapore, 1990.

M. de Moor, 'The importance of gold jewellery in Nias culture', in: J.A. Feldman (et al.), Nias, tribal treasures; cosmic reflections in stone, wood and gold, Delft, 1990.

J.-L. Nou and L. Frédéric, Borobudur, Paris, 1994.

S. Rodgers, Power and gold; jewelry from Indonesia, Malaysia, and the Philippines from the collection of the Barbier-Mueller Museum Geneva, Geneva, 1995.

B. Sellato, Hornbill and dragon; arts and culture of Borneo, Singapore, 1992.

W.F. Stutterheim, Rama-Legenden und Rama-Reliefs in Indonesien, München, 1925.

W.F. Stutterheim, 'Voorloopig bericht omtrent enkele vondsten op den Penanggoengan in 1935', Djawa 16 (1936), pp. 194-200 (Stutterheim 1936a).

W.F. Stutterheim, 'The exploration of Mount Penangungan, Eastern Java', Annual Bibliography of Indian Archaeology 11 (1936), pp. 25-30 (Stutterheim 1936b).

W.F. Stutterheim, 'Oudheidkundig verslag over 1936', Oudheidkundig Verslag 7 (1936), pp. 9-11 (Stutterheim 1936c).

R. Wassing-Visser, Sieraden en lichaamsversiering uit Indonesië, Delft, 1984.

\section{Notes}

1. Lunsingh Scheurleer and Klokke 1988. This catalogue was also published under the title Ancient Indonesian Bronzes; a catalogue of the exhibition in the Rijksmuseum Amsterdam with a general introduction by Brill in Leiden in the same year.

2. Stutterheim 1936a, 1936b, 1936c.

3. Stutterheim 1936a, p. 200.

4. Information from Pauline Lunsingh Scheurleer.

5. Budaya Indonesia 1987, pp. 14 (no. 2), 15 (no. 3), 85 (nos. 4, 7), 86 (nos. 8, 10 ), 88 (no. 13), 89 (no. 15, see also pl. 3), 90 (nos. 19, 20), 92 (nos. 23, 25).

6. I am grateful to Marischka de Louw of the Collections Department of the Tropenmuseum Amsterdam for weighing the earring and sending me this information. She notes that the scales used to weigh the earring are not extremely precise.

7. Miksic 1990, pp. 76-78, 112-114. Most of these gold ear ornaments are, it must be mentioned, also slightly smaller than this bronze earring.

8. De Moor 1990, p. 118.

9. Rodgers 1995 , p. 330 , see under no. 124 , see also p. 175 and p. 177.

10. Rodgers 1995, p. 173, pl. 129, see also p. 175 and p. 177.

11. Very clearly, for instance, in representations of Laksmana (Stutterheim 1925, II, pls. 39, 42, 43), of Rama (Stutterheim 1925, II, pls. 44, 48, 85), and of Sita 
12. See Miksic 1988 and Miksic 1990. Miksic distinguishes various types of early earrings (Miksic 1990. pp. 76-78) and, on the basis of their cross-section, U-, V-, Sor D-shaped later earrings (Miksic 1990, p. 111).

13. Miksic 1990, p. 65 (group 10, the lower right example), 68 (group 12, the larger examples).

14. Rodgers 1995 , p. 324 , no. 48.

15. See Rodgers 1995, pp. 123, 280 (nos. 47-50), 324 (nos. 44-50) and Wassing-Visser 1984, p. 139, pl. 240, 140 (no. 638 = TIM-A 391-13.). Sellato 1992, pl. 254, 262.

16. The catalogue Power and Gold contains a photograph of a Penan Dayak man wearing this type of spiral-shaped earrings with the aso motif in his elongated earlobes (Rodgers 1995, p. 117, pl. 94).

17. It differs from most ancient Javanese mirrors known to us in the way the handle is attached to the mirror. In the more common examples, from the East Javanese period ( $10^{\text {th }}$ to $15^{\text {th }}$ century) it is attached to the raised rim of the round disc, so that the hand holds the mirror below the mirror disc instead of behind it.

18. Krom and van Erp 1920-1931 and Nou and Frédéric 1994, relief nos. O 101, 102, $126,130,137,143$ and $147,149,155,160$.

19. Krom and van Erp 1920-1931 and Nou and Frédéric 1994, relief nos. I Ba 214 , 371.

20. I am grateful to Jaap Polak for reminding me of this relief.

21. Krom and van Erp 1920-1931 and Nou and Frédéric 1994, relief no. I b 51.

22. Bernet Kempers 1976, pp. 255 (pl. 181), 256-258. Unfortunately he does not give a source for this information.

23. As told in one of the birth stories (jataka) of the Buddha, the Bhallatiya Jataka, which is no. 504 in the Pali Jataka (see Cowell 1973, IV, pp. 271-275).

24. Krom and van Erp 1920-1931 and Nou and Frédéric 1994, relief nos. II 20, 23, 30, $38,105,121,123,124$, and III $2,14,22,24,27,28,30,43,49,51,52,55,65,75$, 76,80 . 